\title{
Host Factor for Coliphage Q $\beta$ RNA Replication as an Aid in Elucidating Phylogenetic Relationships: The Genus Pseudomonas
}

\author{
By MICHAEL S. DUBOW* AND THOMAS RYAN† \\ Department of Microbiology, Indiana University, \\ Bloomington, Indiana 47401, U.S.A.
}

(Received 4 April 1977)

\begin{abstract}
Host Factor (HF) is a heat-stable RNA-binding protein required along with $\mathrm{Q} \beta$ replicase for in vitro transcription of coliphage $\mathrm{Q} \beta$ RNA. We have found that $\mathrm{HF}$ activity and antigenicity are conserved among certain Gram-negative bacterial species. We examined selected species within the genus Pseudomonas for the presence of the HF polypeptide's antigenicity and $\mathrm{Q} \beta$ RNA replication function. While we were unable to detect either of these in Pseudomonas diminuta or Pseudomonas vesicularis, the other eleven species tested contained cross-reacting material to Escherichia coli HF. Furthermore, in six of these eleven species we were able to detect HF activity. The detection of HF structure and function allowed the examined species to be grouped into three categories which we have called 'sets'. The results correlate well with those of previous studies on ribosomal RNA homology (Palleroni et al., 1973).
\end{abstract}

\section{INTRODUCTION}

The elucidation of phylogenetic relationships among bacterial species is a complex and confusing problem. The lack of a fossil record has forced the study of bacterial evolution to rely on an examination of the degree of similarity among extant organisms. Taxonomic schemes based upon studies of morphology, nucleic acid homologies and intermediary metabolism have not always resulted in the unambiguous elucidation of phylogenetic relationships (Palleroni \& Doudoroff, 1972). One such group whose phylogeny has not proven amenable to these approaches is the genus Pseudomonas. Palleroni et al. (1973) have, on the basis of ribosomal RNA homology studies, divided the genus into five groups some of which appear to be as related to Escherichia coli as they are to each other. Clearly, other approaches are desirable in order to unravel the taxonomic inconsistencies inherent in such a large, artificially created collection of species.

One approach is to examine the evolutionary conservation of the structure and function of proteins (see, for example, Patel \& Ornston, 1976). We have found that Host Factor (HF) for coliphage $\mathrm{Q} \beta$ RNA replication appears to have the correct 'range' to assist in the determination of the phylogeny of the genus Pseudomonas.

$\mathrm{Q} \beta$ is one of the small, sex-specific RNA coliphages. It replicates its single-stranded RNA genome using the four-subunit enzyme, $\mathrm{Q} \beta$ replicase (for a review, see Zinder, 1975). Only the polypeptide called synthetase is specified by the $\mathrm{Q} \beta$ genome. The other three subunits are present in uninfected $E$. coli and normally perform roles in protein synthesis. In addition, a fourth protein present in uninfected $E$. coli is required for the initiation of transcription

* Present address: The Cold Spring Harbor Laboratory, P.O. Box 100, Cold Spring Harbor, New York 11724 , U.S.A.

$\dagger$ Present address: Center for Neural Sciences, Chemistry Building, Indiana University, Bloomington, Indiana 4740I, U.S.A. 
of Q $\beta$ RNA (Shapiro, Franze de Fernandez \& August, 1968; Franze de Fernandez, Eoyang \& August, 1968). This protein, known as Host Factor (HF), is a I 2000 molecular weight polypeptide, usually found as a hexamer, that is stable at temperatures up to $90^{\circ} \mathrm{C}$ for $5 \mathrm{~min}$ (Franze de Fernandez, Hayward \& August, 1972). In uninfected E. coli, the great majority of $\mathrm{HF}$ is found associated with the $30 \mathrm{~S}$ ribosomal subunit (Carmichael et al., 1975; DuBow et al., I977). HF is an RNA-binding protein that binds tightly to and inhibits the in vitro translation of poly(A), but not poly(U) (Carmichael et al., I975). In addition, HF binds to $\mathrm{R}_{17}$ and $\mathrm{Q} \beta$ phage RNAs through the apparent recognition sequence AAUAAA (Senear \& Steitz, 1976).

We have previously reported the presence in Pseudomonas putida of an I 000 molecular weight polypeptide that cross-reacts serologically with $E$. coli $\mathrm{HF}$ and is equally active in allowing in vitro $\mathrm{Q} \beta$ RNA replication (DuBow \& Blumenthal, I975). In order to determine the evolutionary conservation of HF, we screened a number of different bacterial species for the presence of HF. We found that HF was present in some, but not all, Gram-negative species (DuBow et al., 1977) but could not be detected in any Gram-positive species tested. It therefore seemed reasonable that the presence or absence of HF among certain Gramnegative bacterial species might be a useful tool in contributing toward an understanding of phylogenetic relationships.

The genus Pseudomonas was chosen for this study because it has been extensively studied and because it remains a heterogeneous collection of species whose evolutionary taxonomy is largely unresolved (Palleroni \& Doudoroff, 1972). On the basis of HF activity and antigenicity we have found that the genus can be divided into three 'sets'.

\section{METHODS}

Materials. Bacteriological culture media were from Difco. Nucleoside triphosphates were from P-L Biochemicals (Milwaukee, Wisconsin, U.S.A.). Dithioerythritol was from Pierce Chemical (Rockford, Illinois, U.S.A.). Toluene-Omnifluor and [5,6-- $\mathrm{H}] \mathrm{UTP}\left(36.84 \mathrm{Ci} \mathrm{mmol}^{-1}\right)$ were from New England Nuclear. Trizma base and phenylmethylsulphonylfuoride were from Sigma. DNAase (RNAase-free) was from Worthington. $\mathrm{Q} \beta$ RNA, made by the method of Yamamoto et al. (1970), was a gift of Stanley Brown of this laboratory. $\mathrm{Q} \beta$ replicase was prepared according to Kamen (1972) with modifications described previously (Blumenthal, Landers \& Weber, 1972). Escherichia coli HF was purified from a high-salt ribosomal wash (Nishizuka, Lipmann \& Lucas-Lenard, 1968) according to $\mathrm{K}$ amen et al. (1972). Escherichia coli $\mathrm{HF}$ antiserum was a gift of Gordon Carmichael.

Assays. HF assays and Ouchterlony immunodiffusion analyses were performed as described previously (DuBow \& Blumenthal, 1975). Crude extracts (S-30) and heat-treated crude extracts were prepared according to DuBow et al. (1977).

Organisms and growth. Bacterial strains and their sources are listed in Table I. All species (with the exception of Pseudomonas acidovorans) were grown on $2 \times$ broth ( $16 \mathrm{~g}$ nutrient broth, $4 \mathrm{~g} \mathrm{NaCl}$ and $\mathrm{g} \mathrm{g} \mathrm{D-glucose} \mathrm{per}$ litre $\mathrm{H}_{2} \mathrm{O}$ ). Pseudomonas acidovorans was grown on L-broth ( $10 \mathrm{~g}$ tryptone, $10 \mathrm{~g} \mathrm{NaCl}$ and $5 \mathrm{~g}$ nutrient broth per litre $\mathrm{H}_{2} \mathrm{O}$ ). All organisms were harvested at the late-exponential phase of growth by centrifuging in a Sorvall GSA rotor at $9000 \mathrm{rev} . \mathrm{min}^{-1}$ for $20 \mathrm{~min}$ at $4{ }^{\circ} \mathrm{C}$.

\section{RESULTS}

\section{Detection of $\mathrm{HF}$ antigen}

Purified $P$. putida HF forms a band of partial identity in an Ouchterlony immunodiffusion plate when tested against $E$. coli HF using $E$. coli HF antiserum (DuBow \& Blumenthal, 1975). A band of partial identity is also formed if S-30 fractions are used instead of the purified proteins (DuBow et al., 1977). The S-30 fractions from the Pseudomonas species listed in Table I were tested for the presence of antigenic material which would cross-react with antiserum prepared against purified $E$. coli HF. We found that S-30 fractions from all but two of the species tested contained cross-reacting material (Fig. I). The S-30 fractions from $P$. vesicularis and $P$. diminuta did not contain detectable $E$. coli $\mathrm{HF}$ cross-reacting 
Table I. Host factor (HF) activity and antigenicity in pseudomonads

HF activity and antigenicity were determined as described by DuBow \& Blumenthal (1975).

Set

A

B

C Pseudomonas diminuta

Pseudomonas vesicularis

$\begin{array}{rc}\text { Strain } & \text { ATCC } \\ \text { no. } & \text { no. } \\ \text { I31 } & 17503 \\ \text { E38 } & 13985 \\ \text { A90 } & 12633 \\ 221 & 17588 \\ 67 & 13637 \\ 1127 & \\ 134 & 17506 \\ 332 & 17695 \\ 14 & 15668 \\ 382 & 17759 \\ 1047 & \\ 501 & 11568 \\ 500 & 11426\end{array}$

Source*
Indiana
Berkeley
Indiana
Berkeley
Berkeley
Purdue
Berkeley
Berkeley
Berkeley
Berkeley
Purdue
Berkeley
ATcC

HF HF antigen $\dagger$ activity

$+$

$+$

$+$

$+$

$+$

$+$

$+$

$+$

$+$

$+$

* Berkeley: Department of Bacteriology and Immunology, University of California at Berkeley, Berkeley, California 94720, U.S.A.; ATCC: American Type Culture Collection, Rockville, Maryland 20852, U.S.A.; Indiana: Dr George Hegeman, Department of Microbiology, Indiana University, Bloomington, Indiana 4740I, U.S.A.; Purdue: Dr W. R. Stevenson, Department of Botany and Plant Pathology, Purdue University, West Lafayette, Indiana 47907 , U.S.A.

++ , Present; - absent.

$\ddagger+$, At least an eightfold increase in incorporation into acid-precipitable material over background; -, no detectable increase in incorporation over background; ND, not determinable (see text).

material (Fig. 2). To investigate the possibility of the presence of an inhibitor in these two S-30 fractions, purified $E$. coli $\mathrm{HF}$ was added to each fraction to yield a final concentration equivalent to that present in an $E$. coli S-30 fraction. The S-30 fractions from these two species containing exogenous $E$. coli $\mathrm{HF}$ formed bands of complete identity in an Ouchterlony immunodiffusion plate when tested against an S-30 fraction from $E$. coli (Fig. 2).

\section{$H F$ activity in heat-treated crude extracts}

We have previously shown that the ability of a heat-treated crude extract from $P$. putida to stimulate $\mathrm{Q} \beta$ RNA replication in vitro by $\mathrm{Q} \beta$ replicase is due to the presence of the $\mathrm{HF}$ polypeptide (DuBow \& Blumenthal, 1975). RNA synthesis is totally dependent on the presence of both $\mathrm{Q} \beta$ RNA and $\mathrm{Q} \beta$ replicase. We have now tested heat-treated crude extracts from other Pseudomonas species for functional activity in this assay (Table 1 ).

The S-30 fractions from $P$. diminuta and $P$. vesicularis (set $C$ ) did not contain detectable HF antigen and their heat-treated crude extracts failed to stimulate $Q \beta$ RNA replication in vitro. However, when saturating amounts of purified $E$. coli $\mathrm{HF}$ were added to the reaction, $\mathrm{Q} \beta$ RNA replication was almost fully stimulated. Thus, no inhibitor is present.

Heat-treated crude extracts from the other eleven species, all of whose S-30 fractions contained detectable HF antigen, were also tested for their ability to stimulate $\mathrm{Q} \beta$ RNA replication in vitro. We were able to detect $\mathrm{HF}$ activity in six of these eleven species (set $A$ ). The heat-treated crude extracts from the other five species failed to stimulate $\mathrm{Q} \beta$ RNA replication in vitro. However, we were also unable to detect in vitro $\mathrm{Q} \beta$ RNA replication above the background level with these heat-treated crude extracts when saturating amounts of purified $E$. coli $\mathrm{HF}$ were added to the reactions. Thus, it seems that the S-30 fractions from these five species contain a heat-stable inhibitor of the $Q \beta$ RNA replication reaction (set B). 


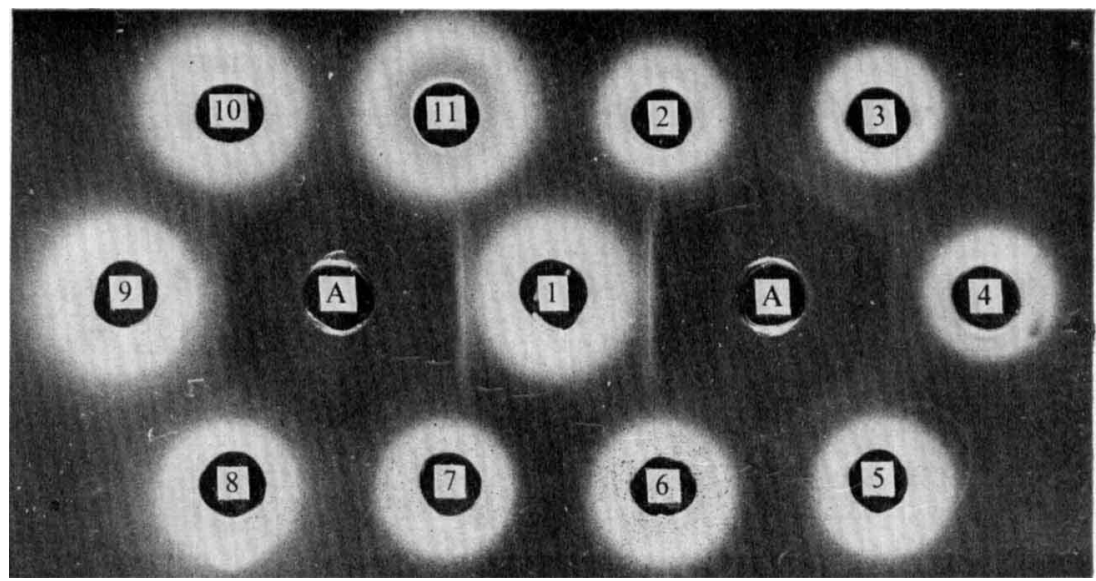

Fig. 1. HF antigenicity in sets A and B. Ouchterlony double diffusion analysis was performed as described previously (DuBow \& Blumenthal, 1975). The centre wells each contained $20 \mu l$ of antiserum (A) prepared against purified $E$. coli HF. The outer wells contained $50 \mu l$ of S-30 fractions from the following organisms: $1, E$. coli; $2, P$. cepacia; $3, P$. solanacearum ;,$P$. aeruginosa; 5, P. stutzeri; 6, P. fuorescens; 7, Xanthomonas vesicatoria; $8, P$. maltophilia; $9, P$. acidovorans; I0, $P$. facilis; I , $P$. delafieldii.

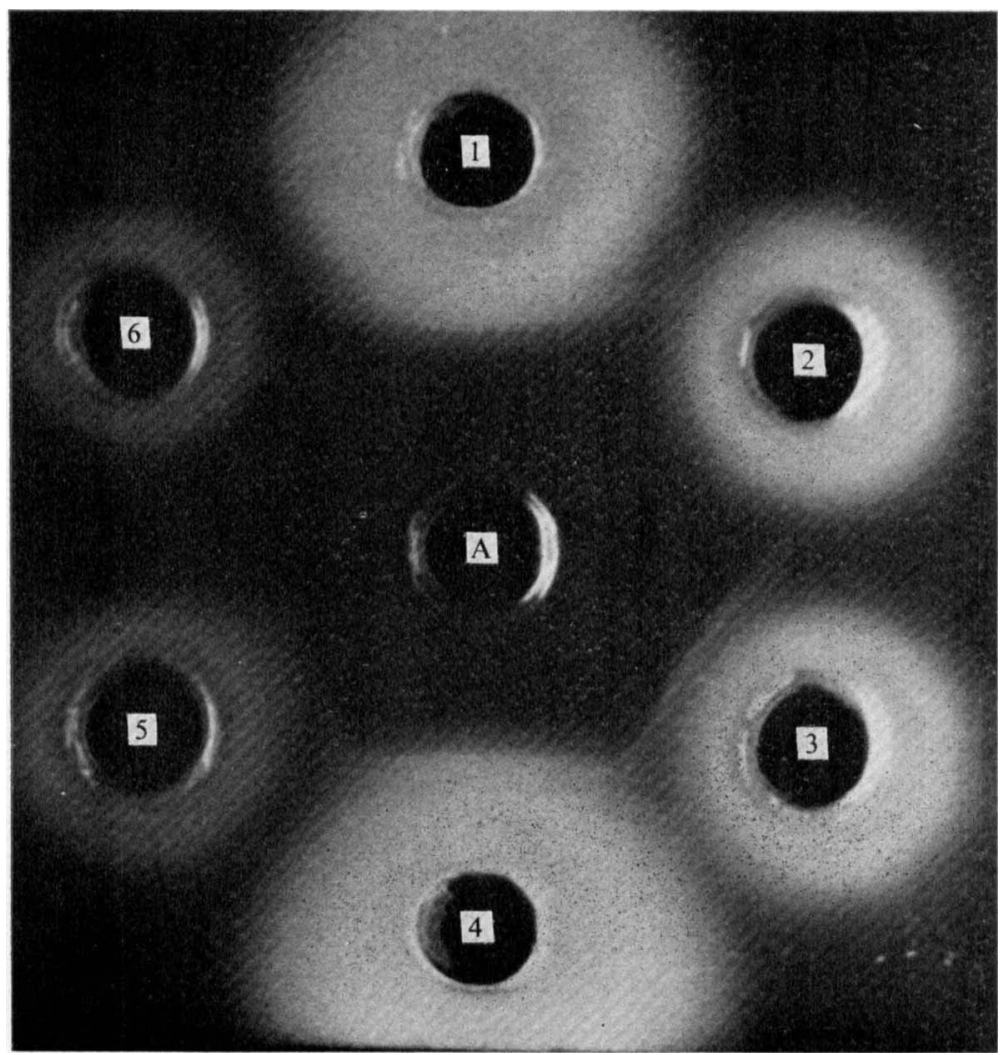

Fig. 2. HF antigenicity in $P$. vesicularis and $P$. diminuta (set $C$ ). Ouchterlony double diffusion analysis was performed as described previously (DuBow \& Blumenthal, 1975). The centre well contained $10 \mu \mathrm{l}$ of antiserum (A) prepared against purified $E$. coli HF. The outer wells contained: I and $4,20 \mu \mathrm{l} \mathrm{S}-30$ fraction from $E$. coli; 2, $20 \mu \mathrm{l} \mathrm{S-30}$ fraction from $P$. diminuta; 3, $20 \mu \mathrm{l} \mathrm{S-30}$ fraction from $P$. diminuta containing $0.1 \mu \mathrm{g}$ purified $E$. coli HF; 5, $20 \mu \mathrm{l}$ S-30 fraction from $P$. vesicularis containing $0 \cdot 1 \mu \mathrm{g}$ purified $E$. coli $\mathrm{HF} ; 6,20 \mu \mathrm{l} \mathrm{S-30}$ fraction from $P$. vesicularis. 


\section{DISCUSSION}

We have previously shown that the presence of Host Factor (HF) for coliphage Q $\beta$ RNA replication appears to be a useful criterion in the elucidation of phylogenetic relationships among some Gram-negative bacterial species (DuBow \& Blumenthal, 1975; DuBow et al., 1977). On the basis of our detection of $\mathrm{HF}$ antigen and $\mathrm{Q} \beta$ RNA replication activity within certain species of the genus Pseudomonas, we are able to distinguish three categories which we refer to as 'sets'.

By rRNA homology studies, Palleroni et al. (1973) divided the genus Pseudomonas into five 'groups'. They included in their study representative species of the genus Xanthomonas which, by some criteria, appear closely related to the pseudomonads. Palleroni et al. (1973) also found that some of the 'groups' within the genus Pseudomonas are, by rRNA homology, as closely related to $E$. coli as they are to each other, a finding that supports the contention that this genus is an artificial and heterogeneous grouping. It is apparent that our sets $\mathrm{A}$ and B correspond to their closely related groups (I and V) and (II and III) respectively. In all of these species, we were able to detect antigenic determinants that would cross-react with E. coli $\mathrm{HF}$ antiserum.

Palleroni et al. (1973) suggested that the five rRNA homology groups exhibit a sufficient degree of unrelatedness to warrant the creation of separate genera. The existence of enough known phenotypic characters to distinguish all the species from one group from those of another is perhaps only present for $P$. dimunuta and $P$. vesicularis (our set C; Palleroni et al., 1973, group IV) which have some unique properties. For example, $P$. diminuta and $P$. vesicularis are two of only three pseudomonads that require growth factors (Palleroni \& Doudoroff, 1972). Perhaps the inclusion of these two species within the genus Pseudomonas does not reflect true phylogenetic relationships but, rather, may be due to convergent evolution.

$\mathrm{HF}$ is an RNA-binding protein that is found associated with ribosomes in E. coli (Carmichael et al., 1975) and $P$. putida (DuBow \& Blumenthal, 1975). In E. coli we have found that $\mathrm{HF}$ is associated with the $30 \mathrm{~S}$ ribosomal subunit (DuBow et al., 1977). It is interesting to note that the conservation of HF parallels that of the 3 -terminal sequence of prokaryotic I6S rRNA (Shine \& Dalgarno, 1975) and translational specificity of ribosomes (Stallcup, Sharrock \& Rabinowitz, 1974), which has been shown to be determined by the 30 S ribosomal subunit (Leffler \& Szer, I973). It is thus not surprising that our results on the conservation of the HF polypeptide correlate well with the rRNA homology studies of Palleroni et al. (1973).

The authors would like to thank R. Contopoulou, W. R. Stevenson and George Hegeman for their generous gifts of the bacterial strains used in this study. We are further indebted to George Hegeman for many fruitful discussions and ideas, and Thomas Blumenthal for providing the stimulating environment in which this research was performed. M.D. was supported by Training Grant GM-82 from the National Institute of General Medical Sciences. The research was supported by NIGMS Grant GM-21024 to T. Blumenthal. 


\section{REFERENCES}

Blumenthal, T., Landers, T. A. \& Weber, $K$. (1972). Bacteriophage $Q \beta$ replicase contains the protein biosynthesis elongation factors EFTu and EFTs. Proceedings of the National Academy of Sciences of the United States of America 69, 1313-1317.

Carmichael, G. G., Weber, K., Niveleau, A. \& WAHBA, A. J. (1975). The Host Factor required for RNA phage $Q \beta$ RNA replication in vitro. Intracellular location, quantitation, and purification by poly(A)-cellulose column chromatography. Journal of Biological Chemistry 250, 3607-36I 2.

DuBow, M.S. \& Blumenthal. T. (1975). Host Factor for coliphage $Q \beta$ RNA replication is present in Pseudomonas putida. Molecular and General Genetics 141, $113-119$.

DuBow, M. S., Ryan, T., Young, R. A. \& BluMENTHAL, T. (I977). Host Factor for coliphage $\mathbf{Q} \beta$ RNA replication: presence in procaryotes and association with the $30 S$ ribosomal subunit in Escherichia coli. Molecular and General Genetics I53, 39-43.

Franze DE Fernandez, M. T., Eoyang, L. \& AUGUST, J. T. (1968). Factor fraction required for the synthesis of bacteriophage $Q \beta$ RNA. Nature, London 219, 588-590.

Franze de Fernandez, M. T., Hayward, W. S. \& August, J. T. (1972). Bacterial proteins required for replication of phage $Q \beta$ ribonucleic acid. Purification and properties of Host Factor I, a ribonucleic acid-binding protein. Journal of Biological Chemistry 247, 824-831.

KAMEN, R. (1972). A new method for the purification of $\mathbf{Q} \beta$ RNA-dependent RNA polymerase. Biochimica et biophysica acta 262, 88-100.

Kamen, R., Kondo, M., Roemer, W. \& WeismanN, C. (1972). Reconstitution of $Q \beta$ replicase lacking subunit $\alpha$ with protein synthesis interference factor i. European Journal of Biochemistry 31, 44-5I.

LEFFLER, S. \& SzER, W. (1973). Messenger selection by bacterial ribosomes. Proceedings of the National
Academy of Sciences of the United States of America 70, 2364-2368.

Nishizuka, Y., LipmanN, F. \& Lucas-Lenard, J. A. (1968). Isolation and properties of the Escherichia coli amino acid polymerizing enzyme. Methods in Enzymology 12, 708-721.

Palleron, N. J. \& Doudoroff, M. (1972). Some properties and taxonomic subdivisions of the genus Pseudomonas. Annual Review of Phytopathology 10, 73-100.

Palleroni, N. J., Kunisawa, R., Contopoulou, R. \& Doudoroff, M. (1973). Nucleic acid homologies in the genus Pseudomonas. International Journal of Systematic Bacteriology 23, 333-339.

Patel, R. N. \& ORnston, O. N. (1976). Immunological comparison of enzymes of the $\beta$-ketoadipate pathway. Archives of Microbiology I10, 27-36.

Senear, A. W. \& Steitz, J. A. (1976). Site-specific interaction of $\mathrm{Q} \beta$ Host Factor and ribosomal protein $\mathrm{SI}$ with $\mathrm{Q} \beta$ and $\mathrm{R}_{17}$ bacteriophage RNA's. Journal of Biological Chemistry 251, 1902-1912.

Shapiro, L., Franze de Fernandez, M. T. \& August, J. T. (1968). Resolution of two factors required in the $\mathrm{Q} \beta$-RNA polymerase reaction. Nature, London 220, 478-480.

Shine, J. \& Dalgarno, L. (I975). Terminal-sequence analysis of bacterial ribosomal RNA. Correlation between the $3^{\prime}$-terminal polypyrimidine sequence of I6S RNA and translational specificity of the ribosome. European Journal of Biochemistry 57, 22 I-230.

Stallcup, M. R., Sharrock, W. J. \& Rabinowitz, J. C. (1974). Ribosome and messenger specificity in protein synthesis by bacteria. Biochemical and Biophysical Research Communications 58, 92-98.

Yamamoto, K. R., Alberts, B. M., Benzinger, R., LaWhorne, L. \& Treiber, G. (1970). Rapid bacteriophage sedimentation in the presence of polyethylene glycol and its application to large scale virus purification. Virology 40, 734-744.

ZINDER, N. D. (editor) (1975). RNA Phages. New York: Cold Spring Harbor Laboratory. 